Article

\title{
Novel Water Soluble Chitosan Derivatives with 1,2,3-Triazolium and Their Free Radical-Scavenging Activity
}

\author{
Qing $\mathrm{Li}^{1}$, Xueqi Sun ${ }^{1,2}$, Guodong $\mathrm{Gu}^{3}$ and Zhanyong Guo ${ }^{1, * \mathbb{B}}$ \\ 1 Key Laboratory of Coastal Biology and Bioresource Utilization, Yantai Institute of Coastal Zone Research, \\ Chinese Academy of Sciences, Yantai 264003, Shangdong, China; qli@yic.ac.cn (Q.L.); \\ cafeapril@163.com (X.S.) \\ 2 Graduate School of Chinese Academy of Sciences, Beijing 100039, China \\ 3 Alliance Pharma, Inc., 17 Lee Boulevard Malvern, PA 19355, USA; guguodong011@gmail.com \\ * Correspondence: zhanyongguo@hotmail.com; Tel.: +86-535-2109171
}

Received: 9 February 2018; Accepted: 24 March 2018; Published: 28 March 2018

check for updates

\begin{abstract}
Chitosan is an abundant and renewable polysaccharide, which exhibits attractive bioactivities and natural properties. Improvement such as chemical modification of chitosan is often performed for its potential of providing high bioactivity and good water solubility. A new class of chitosan derivatives possessing 1,2,3-triazolium charged units by associating "click reaction" with efficient 1,2,3-triazole quaternization were designed and synthesized. Their free radical-scavenging activity against three free radicals was tested. The inhibitory property and water solubility of the synthesized chitosan derivatives exhibited a remarkable improvement over chitosan. It is hypothesized that triazole or triazolium groups enable the synthesized chitosan to possess obviously better radical-scavenging activity. Moreover, the scavenging activity against superoxide radical of chitosan derivatives with triazolium $\left(\mathrm{IC}_{50}<0.01 \mathrm{mg} \mathrm{mL}^{-1}\right)$ was more efficient than that of derivatives with triazole and Vitamin C. In the 1,1-diphenyl-2-picrylhydrazyl (DPPH) and hydroxyl radical-scavenging assay, the same pattern were observed, which should be related to the triazolium grafted at the periphery of molecular chains.
\end{abstract}

Keywords: chitosan derivatives; 1,2,3-triazolium; free radical-scavenging activity

\section{Introduction}

Oxidation is an essential biological process to many organisms for the production of energy, and free radical at certain concentration is necessary for biological system. Free radicals in the human body can help transmit energy to sustain life motivation, kill bacteria and parasites, and help the body to eliminate toxins. However, the uncontrolled production of oxygen derived free radicals triggers many health problems such as Alzheimer disease, Parkinson's disease, and ischemic-reperfusion injury [1]. Oxidative stress is caused by an imbalance between the production and consumption of oxidative species, and often involves reactions between free radicals and molecules of high biological importance, such as lipids, proteins, and DNA [2]. Moreover, restrictions over the use of synthetic antioxidants such as butyl hydroxyl anisd (BHA) and butylated hydroxytoluene (BHT) in food further strengthen the concept of using naturally occurring compounds as antioxidants [3]. Recently, many researches have reported the antioxidant capacity of nature polymers and saccharides, some of which have good free radicals scavenging ability and even have anticancer activity [4-6]. Polysaccharides derivatives are increasingly reported for their potential applications as antioxidants or free radical scavengers [7-12].

Chitosan is a natural, safe, and cheap polysaccharide produced from chitin, the major constituent of arthropods exoskeleton and fungi cell walls and the second renewable carbon source after 
lignocellulosic biomass. In addition to its low cost of production, chitosan also possesses several favorable biological properties such as biodegradability, biocompatibility and non-allergenicity. Chitosan itself has antioxidant activity on hydroxyl radicals with an $\mathrm{IC}_{50}$ of $0.48 \mathrm{mg} / \mathrm{mL}$ [13]. Many chitosan derivatives obtained by chemical modification were reported to have good antioxidant activity. Fan reported antioxidant activity of silk peptides grafted carboxymethyl chitosan, and the highest scavenging activity of 1,1-diphenyl-2-picrylhydrazyl (DPPH) was $24.86 \%$, $91 \%$ of hydroxyl radical and $36.8 \%$ of $\mathrm{H}_{2} \mathrm{O}_{2}$ at the concentration of $0.5-2.5 \mathrm{mg} / \mathrm{mL}$ [14]. Double quaternized chitosan derivatives showed better scavenging ability than chitosan, with more than $90 \%$ scavenging indices against hydroxyl radicals and DPPH radicals at $1.6 \mathrm{mg} / \mathrm{mL}$ [15].

Triazole derivatives represent an interesting class of heterocyclic compounds; they possess many biological activities such as antimicrobial, anti-tubercular, anti-inflammatory and anticancer activities [16-20]. 1,2,3-Triazolium cations have recently been developed by quaternization of 1,2,3-triazoles with halogenide. Meanwhile, triazole and triazolium are expected to be more efficient anion captor [21], which may help stabilize the free radicals and have a good free radical scavenging ability.

In this paper, we report the design and synthesis of a group of chitosan derivatives with 1,2,3-triazolium as substituent. Firstly, the $\mathrm{C}_{2}-\mathrm{NH}_{2}$ was modified as a quaternary ammonium salt. The quaternary ammonium salt was selected by virtue of water solubility, which could enlarge the application of chitosan as a food preservative or bioactive matrix. Afterwards, 6-azido-6-deoxy chitosan was synthesized as intermediate with azido group at C-6 of chitosan. Then, "click reaction" was selected as the key step to synthesize 1,4-disubstituted-1,2,3-triazolyl chitosan derivative. Terminal alkynes bearing benzene, pyridine, and thiophene were used in "click reaction" to introduce those groups at the periphery of chitosan chains. Afterward, the chitosan derivative bearing 1,2,3-triazolium was obtained by the alkylation of 1,2,3-triazolyl chitosan derivative. The chemical structures of the derivatives were characterized by Fourier Transform Infrared Spectroscopy (FT-IR) and ${ }^{1} \mathrm{H}$ Nuclear Magnetic Resonance $\left({ }^{1} \mathrm{H}\right.$ NMR). We speculated that the aimed products might have improved antioxidant activity, and we investigated the free radical-scavenging activity of chitosan and the synthesized chitosan derivatives. Three types of classic free radicals, including hydroxyl radical, DPPH radical, and superoxide radical, were selected to estimate the radical scavenging ability of chitosan and the synthesized chitosan derivatives.

\section{Results}

\subsection{Chemical Synthesis and Characterization}

In the previous work of our group, $\mathrm{C}_{2}-\mathrm{NH}_{2}$ of chitosan was protected by phthaloyl firstly and treated with aqueous hydrazine monohydrate to remove the phthaloyl protecting group after "click reaction" [22,23]. In this way, amino group could be protected well, but more reaction steps would lead to lower overall yield. In this paper, trimethyl quaternary ammonium salt of chitosan was first synthesized through the reaction of the $\mathrm{C}_{2}-\mathrm{NH}_{2}$ of chitosan and iodomethane (Scheme 1). The quaternary ammonium salt was chosen as polymer part by virtue of its water-solubility in neutral and alkaline aqueous solutions. Meanwhile, the quaternization could protect the amino group in the next bromination reaction of $\mathrm{C}_{6}$-OH. Each step of synthesis was followed by FT-IR and ${ }^{1} \mathrm{H}$ NMR spectroscopy measurements. The FT-IR and ${ }^{1} \mathrm{H}$ NMR spectra of compounds $\mathbf{4}$ and $\mathbf{5}$ are shown in Figures 1 and 2, respectively. 


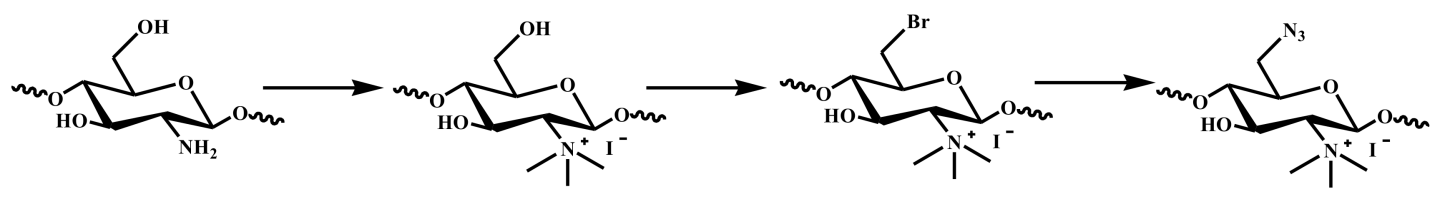

Chitosan

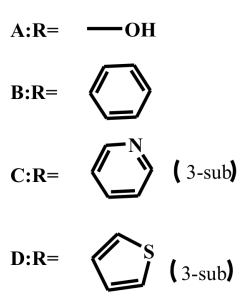

1

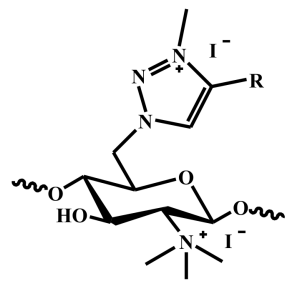

2
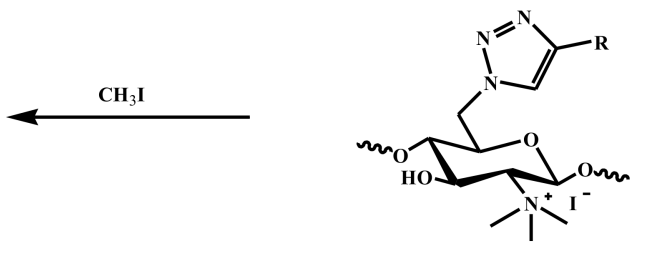

4

Scheme 1. Synthetic routes for the preparation of chitosan derivatives.

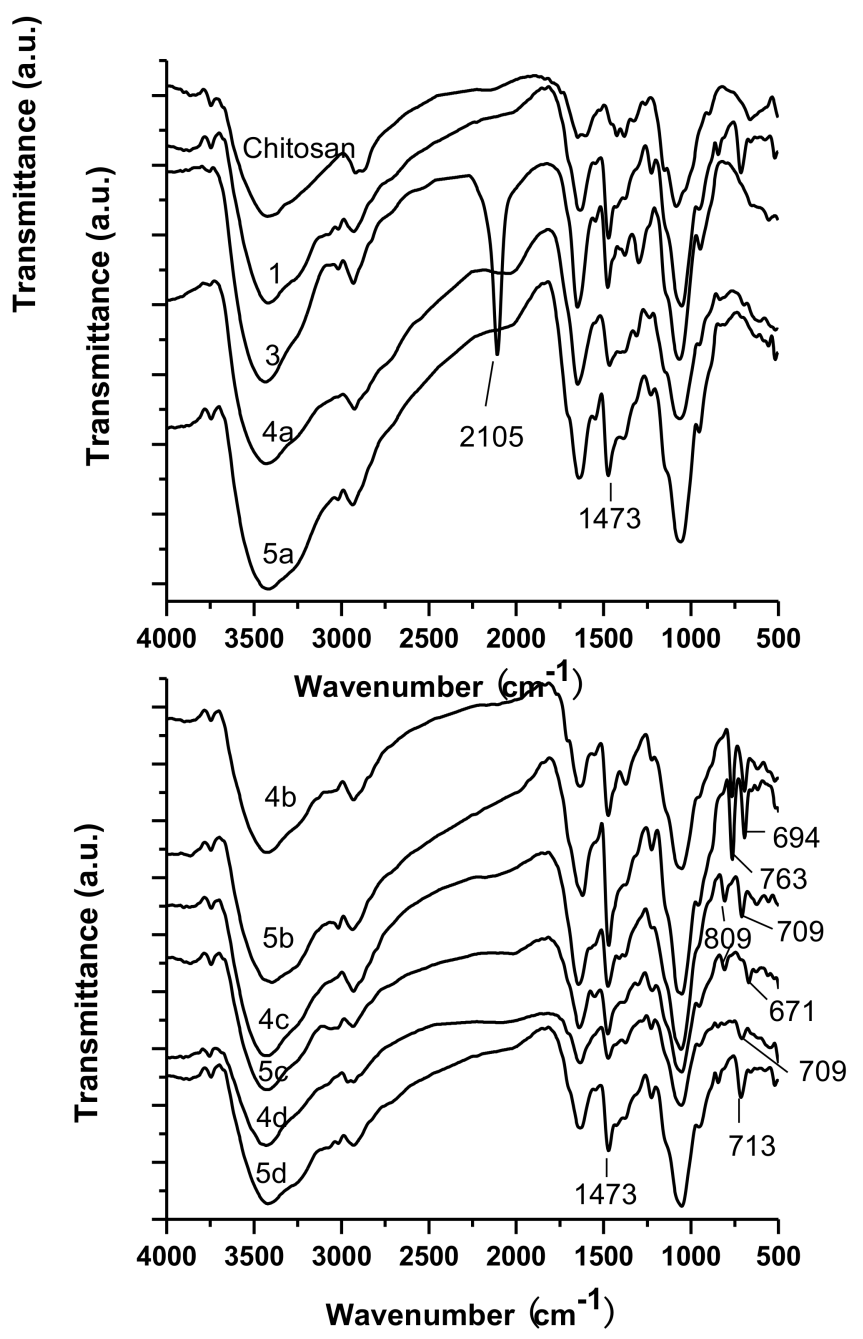

Figure 1. FT-IR spectra of intermediate products and chitosan derivatives 4 (top) and 5 (bottom). 


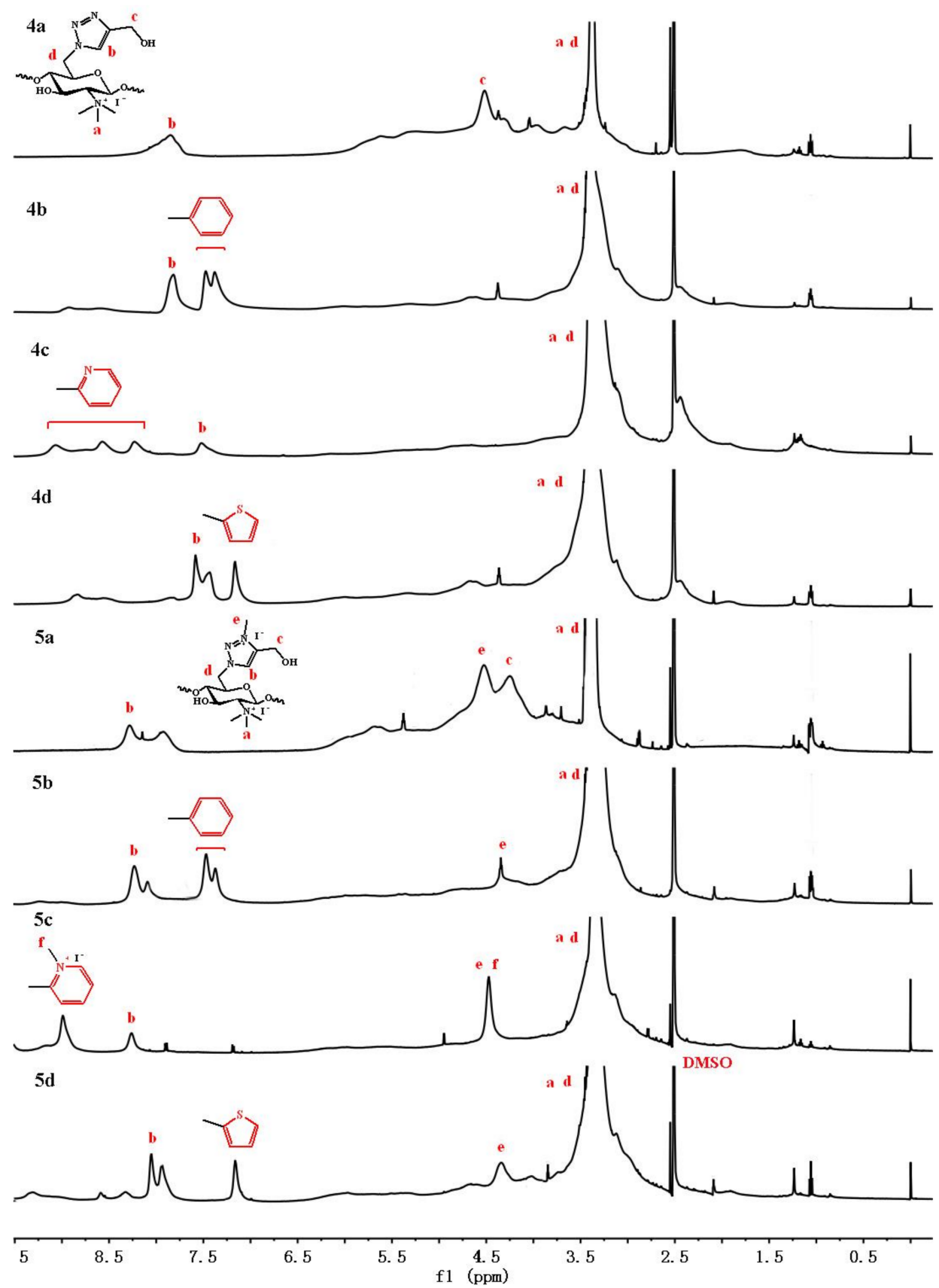

Figure 2. ${ }^{1} \mathrm{H}$ NMR spectra of chitosan derivatives 4 and 5 .

In the FT-IR spectrum of compound 1 (Figure 1), the peak at $1477 \mathrm{~cm}^{-1}$ was ascribed to the deformation vibration of $\mathrm{C}-\mathrm{H}$ in $\mathrm{N}-\mathrm{CH}_{3}$ [24]. Then, $\mathrm{C}-6-\mathrm{Br}$ quaternary ammonium chitosan derivative (2) was synthesized by the reaction between the $\mathrm{C}_{6}-\mathrm{OH}$ with NBS and $\mathrm{Ph}_{3} \mathrm{P}$, as NBS and $\mathrm{Ph}_{3} \mathrm{P}$ could selectively replace primary hydroxyl groups of polysaccharide with bromine [19]. The azidation of compound 2 could be conveniently achieved through a nucleophilic substitution with sodium azide to get 6-azido-6-deoxy- $\mathrm{N}$-phthaloyl quaternary ammonium chitosan. The characteristic peak observed at $2105 \mathrm{~cm}^{-1}$ was the stretching vibration of $-\mathrm{N}=\mathrm{N}^{+}=\mathrm{N}^{-}$for C-6-azido. As long as we got 6-azido-6-deoxy- $N$-trimethyl quaternary ammonium chitosan, the "click chemistry" could be performed in an elegant way with terminal alkynes with heterocycle as substitutes to synthesize the aimed chitosan derivatives [25]. The peak at $2105 \mathrm{~cm}^{-1}$ in spectrum of compound 3 disappeared when the C-6-azido was transformed to 1,2,3-triazoles [26]. New peaks appeared at 767 and $694 \mathrm{~cm}^{-1}$ were 
assigned to the deformation vibration of $\mathrm{C}-\mathrm{H}$ in benzene in the spectrum of $4 \mathbf{b}$, new peaks at 806 and $709 \mathrm{~cm}^{-1}$ were assigned to the deformation vibration of $\mathrm{C}-\mathrm{H}$ in pyridine of $4 \mathrm{c}$, and new peaks at $709 \mathrm{~cm}^{-1}$ were assigned to thiophene of $4 \mathrm{~d}$, respectively (Figure 1). In the ${ }^{1} \mathrm{H}$ NMR spectra, the appearance of the proton in 1,2,3-triazole at 7.58-7.88 ppm further proved the successful "click reaction" (Figure 2). Meanwhile, the new peaks of heterocycle could be clearly observed at 7.38-7.47 ppm for benzene of $4 \mathbf{b}, 8.24-9.07$ for pyridine of $4 \mathbf{c}$, and 7.16 for thiophene of $4 \mathbf{d}$, respectively. Subsequently, alkylation of 1,2,3-triazolyl chitosan derivative (4) was conducted by reacting with iodomethane. In the ${ }^{1} \mathrm{H}$ NMR spectra of 5, the peak corresponding to the proton of the 1,2,3-triazole group shifted from 7.58-7.88 ppm in DMSO- $d_{6}$ to 8.18-8.33, and the N-3 methyl protons of the quaternizing group appeared at $4.34-4.55 \mathrm{ppm}$ [27].

\subsection{Solubility and Radical Scavenging Activity}

The application of chitosan is restricted to only acidic conditions where the $\mathrm{NH}_{2}$ group becomes protonated [28]. The further enhancement of the bioactivity of chitosan over a broader $\mathrm{pH}$ range will promote its application in many areas. The quaternization of chitosan is an important means to improve its solubility. After quaternization, $N$-trimethyl quaternary ammonium chitosan (2) showed favorable water solubility. After the alkylation of 1,2,3-triazolyl chitosan derivative (4), the water solubility of chitosan derivative (5) was further improved. Therefore, compounds 4 and 5 showed better water solubility than chitosan, and could be prepared as aqueous solution $(0.01-1.6 \mathrm{mg} / \mathrm{mL})$ at room temperature.

As chemical protectors, antioxidants are classified on the basis of their mode of action as chain breaking or preventive antioxidants. The chain breaking antioxidants are chemical species able to prevent oxidation by acting as free-radical scavengers. In this case, antioxidants directly react with free radicals, producing significantly less reactive species or turning off the radical chain reaction. The preventive antioxidants retard the oxidation process by indirect pathways, including metal chelation, decomposition of hydroperoxides to nonradical species, repairing of primary antioxidants by hydrogen or electron donation, deactivation of singlet oxygen or sequestration of triplet oxygen, and absorption of UV radiation [2].

Here, we tested the radical scavenging activity using different assay systems such as the superoxide radical-scavenging, DPPH radical-scavenging, and hydroxyl radical-scavenging assay. Chitosan has poor solubility in water, so we used water-soluble low molecular chitosan in antioxidant assay.

The superoxide radical scavenging activity of chitosan and its related derivatives was tested by their ability to bleach the superoxide radical generated from the phenazine methosulfate/nicotinamide adenine dinucleotide (PMS / NADH)reaction (Figure 3) [21]. This assay provides information on the reactivity of test compounds with superoxide free radicals, independently of any enzymatic activity. The generation of superoxide anions was markedly inhibited by Vitamin $C$ with an $\mathrm{IC}_{50}$ value of $0.02 \mathrm{mg} \mathrm{mL}^{-1}$. Our results clearly demonstrated that the synthesized chitosan derivatives (4 and 5) were as effective as Vitamin $C$ in scavenging superoxide radicals. Chitosan showed relatively weak scavenging activity against superoxide radical, and the scavenging index was $34.72 \%$ at $1.6 \mathrm{mg} \mathrm{mL}^{-1}$. In this test the synthesized chitosan derivatives (4 and 5 ) showed much stronger superoxide radical scavenging ability compared with chitosan. Compound $5\left(\mathrm{IC}_{50}<0.01 \mathrm{mg} \mathrm{mL}^{-1}\right)$ was more efficient than compound 4 ( $\mathrm{IC}_{50}$ of $4 \mathbf{a} 0.05 \mathrm{mg} \mathrm{mL}^{-1}, \mathrm{IC}_{50}$ of $4 \mathbf{c} 0.04 \mathrm{mg} \mathrm{mL}^{-1}, \mathrm{IC}_{50}$ of $4 \mathbf{b}$ and $4 \mathbf{d}<0.01 \mathrm{mg} \mathrm{mL}^{-1}$ ). 


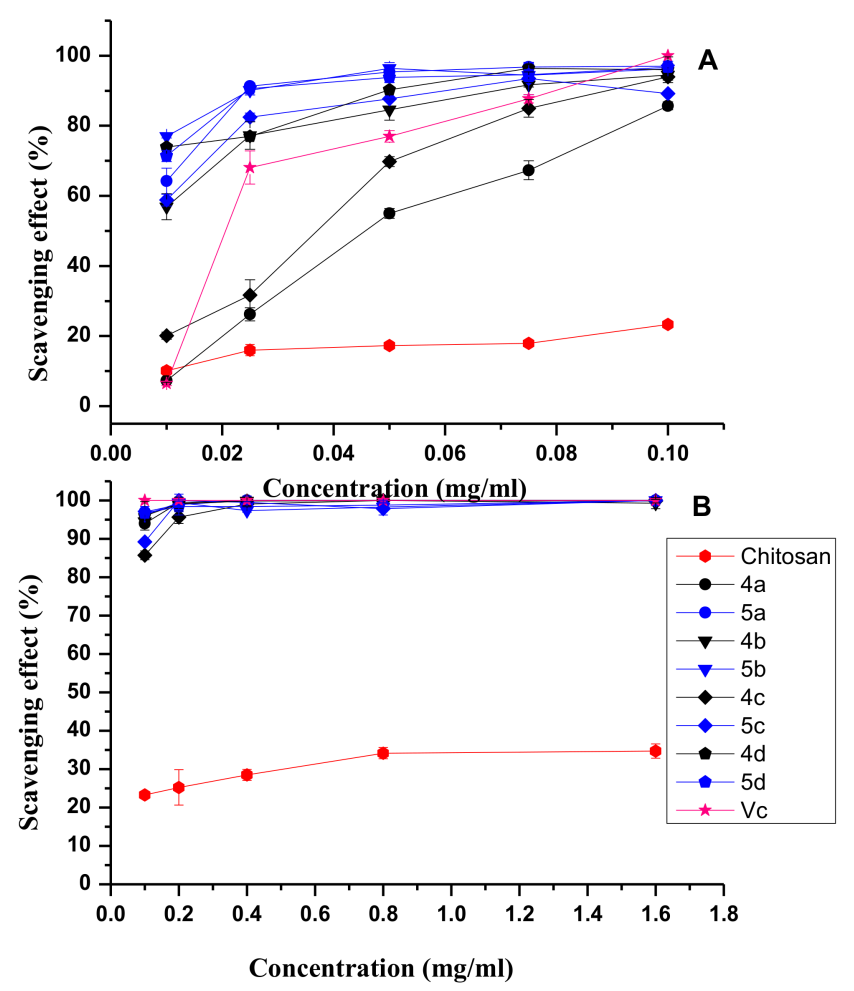

Figure 3. Superoxide-radical scavenging ability of chitosan and chitosan derivatives at different concentrations: (A) $0.01-0.1 \mathrm{mg} / \mathrm{mL}$; (B) $0.1-1.6 \mathrm{mg} / \mathrm{mL}$.

Free radical chain reactions may be inhibited by adding preventive antioxidants that retard the formation of free radicals or stabilize free radicals [21,29]. Owing to the slightly polarized nature of the $\mathrm{C}(5)-\mathrm{H}$ bond, 1,2,3-triazole has gained recognition as excellent hydrogen donor [30], which can form stable free radicals. Meanwhile, the conjugated double bonds allow electron delocalisation across the molecule thus stabilize the radical [1,31]. Furthermore, it is apparent that the chitosan derivatives with triazolium group (5) own better free radical scavenging ability. Because the $\mathrm{C}(5)-\mathrm{H}^{\cdots} \mathrm{A}^{-}$binding ability is strongly enhanced by converting the triazole unit into a triazolium cation, the latter is expected to be a more efficient anion captor [21], which may help stabilize free radicals. The possible action mechanisms may be hydrogen-atom transfer and radical adduct formation [2].

The DPPH radical scavenging activity of chitosan and derivatives synthesized was also evaluated based on their ability to bleach the stable radical DPPH (Figure 4). This assay provided information on the reactivity of the compounds with a stable free radical. Because of the odd electron, DPPH shows a strong absorption band at $517 \mathrm{~nm}$ in visible spectroscopy. As this electron becomes paired off in the presence of a free radical scavenger, the absorption vanishes, and the resulting decolorization is stoichiometric with respect to the number of electrons taken up [1,31]. As a positive control, Vitamin $\mathrm{C}$ was tested with $\mathrm{IC}_{50}<0.1 \mathrm{mg} \mathrm{mL}^{-1}$. Test results showed that chitosan, compound 4 , and compound 5 inhibited DPPH anion formation in a concentration dependent manner, but compound 5 showed more potent scavenging activity $\left(\mathrm{IC}_{50} 0.17-0.51 \mathrm{mg} \mathrm{mL}^{-1}\right.$ ), followed by compound 4 ( $\left.\mathrm{IC}_{50} 0.36-0.72 \mathrm{mg} \mathrm{mL}^{-1}\right)$, and chitosan $\left(17.67 \%\right.$ at $\left.1.6 \mathrm{mg} \mathrm{mL}^{-1}\right)$, respectively. Recently, chemical modification of polysaccharides is increasingly reported for its potential of improving the biological activity of polysaccharides. The experimental data above and related literatures demonstrated that the chemical modification of polysaccharides was conducive to improving the free radical scavenging activity of them. 


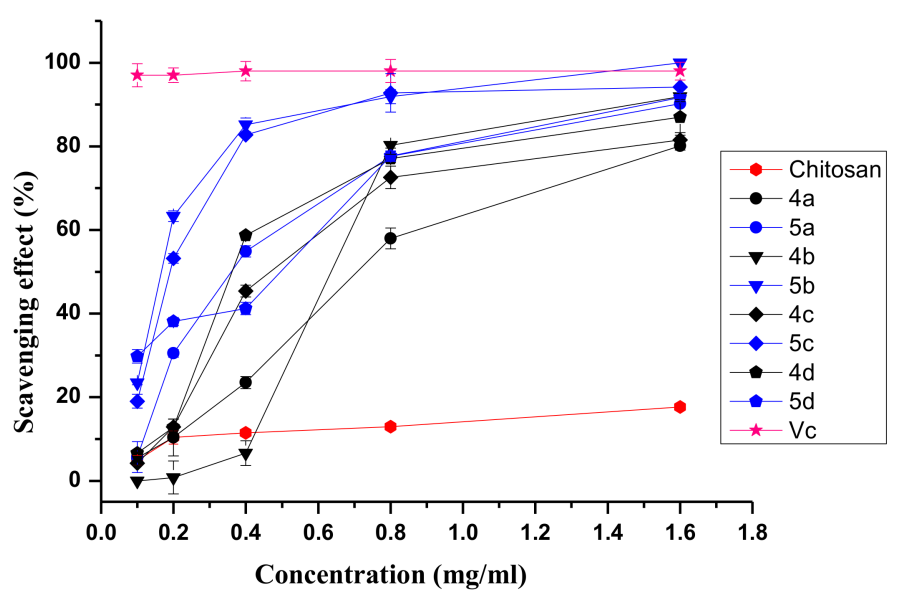

Figure 4. 1,1-diphenyl-2-picrylhydrazyl (DPPH)-radical scavenging ability of chitosan and chitosan derivatives.

Among the oxygen-centered radicals, hydroxyl radical is the most electrophilic and reactive. It is a highly potent oxidant that can react with almost all biomolecules found in living cells. Figure 5 shows the hydroxyl radical scavenging ability of chitosan and the synthesized derivatives at various concentrations. The synthesized chitosan derivatives (4 and 5) also showed much stronger hydroxyl radical scavenging ability compared with chitosan in a concentration-dependent manner. The inhibitory activity was observed in the following order: compound $5\left(\mathrm{IC}_{50}<0.1 \mathrm{mg} \mathrm{mL}^{-1}\right)>$ compound $4\left(\mathrm{IC}_{50} 0.11-0.36 \mathrm{mg} \mathrm{mL}^{-1}\right)>$ chitosan $\left(\mathrm{IC}_{50} 1.53 \mathrm{mg}\right.$ $\mathrm{mL}^{-1}$ ). The results further confirmed that triazole or triazolium groups grafted into the synthesized chitosan derivatives contributed a lot to the radical scavenging action and consequently increased the radical scavenging activity. Superoxide indirectly initiates lipid peroxidation because superoxide anion acts as a precursor of singlet oxygen and hydroxyl radical. Hydroxyl radicals eliminate hydrogen atoms from the membrane lipid, which results in lipid peroxidation. Based on its better free radical-scavenging activity in our experiments, compound $\mathbf{5}$ would have been expected to be superior to compound 4 in lipid peroxidation and the protective effect on oxidative damage induced by $\mathrm{H}_{2} \mathrm{O}_{2}$ in cells.

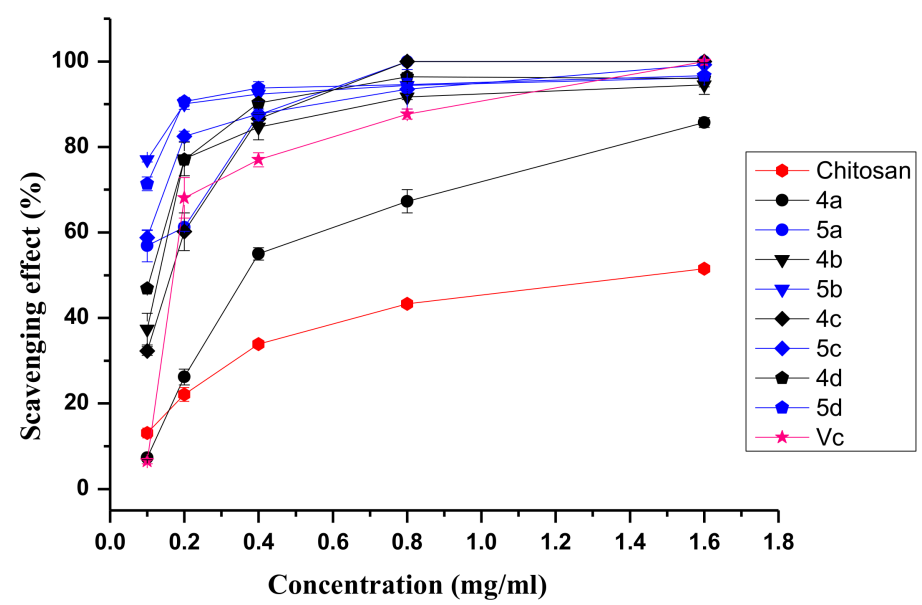

Figure 5. Hydroxyl-radical scavenging ability of chitosan and chitosan derivatives.

On the other hand, the inconsistent relative radical scavenging activity of the synthesized chitosan derivatives against different free radical may be related to the different reaction mechanisms in different systems. There are some fundamental differences among the three assays. First, the features of the 
oxidant such as their redox potentials or stability are not the same. The scavenging effect on DPPH radicals and superoxide radicals represent direct radical scavenging activity. In the hydroxyl radical scavenging assay, hydroxyl radicals are generated by the Fenton reaction and the inhibition could be attributed to the inhibition of radicals or the $\mathrm{Fe}^{2+}$ chelating effectof the test compounds. Second, other factors such as the surface activity affected by the polymer structures and the different reaction mechanisms in different systems may also affect the ability of test compounds to react with and quench different radicals [1].

\section{Materials and Methods}

\subsection{Materials}

Chitosan was purchased from Qingdao Baicheng Biochemical Corp. (Qingdao, China). Its degree of deacetylation is $90 \%$ and the viscosity-average molecular weight is $7.0 \times 10^{4} \mathrm{D}$. Terminal alkynes (propargyl alcohol, ethynylbenzene, 3-ethynylpyridine, and 3-ethynylthiophene) were purchased from Merck Life Science (Shanghai) Co., Ltd., (Shanghai, China) with a minimum purity of $98 \%$. The other reagents such as iodomethane, sodium iodide, sodium hydroxide, cuprous iodide, potassium iodide, potassium bromide $(\mathrm{KBr})$, and solvents are analytical grade and were supplied by Sinopharm Chemical Reagent Co., Ltd., Shanghai, China.

\subsection{Analytical Methods}

FT-IR spectra were measured on a Jasco-4100 Fourier Transform Infrared Spectroscopy (Tokyo, Japan), provided by JASCO Co., Ltd., Shanghai, China) with KBr disks. ${ }^{1} \mathrm{H}$ Nuclear Magnetic Resonance ( ${ }^{1} \mathrm{H}$ NMR) was measured with a Bruker AVIII-500 Spectroscopy with TCI Cryo Probe (Bruker Tech. and Serv. Co., Ltd., Beijing, China). The elemental analyses (C, H, and N) were performed on a Vario Micro Elemental Analyzer (Elementar, Langenselbold, Germany). The Degree of Substitution (DS) was calculated based on elemental analysis results.

\subsection{The synthesis of Chitosam Derivatives}

\subsubsection{Synthesis of 6-Azido-6-deoxy- $N$-trimethyl Quaternary Ammonium Chitosan (3)}

The synthetic routes for the preparation of chitosan derivatives are shown in Scheme 1.

$\mathrm{N}$-trimethyl quaternary ammonium chitosan (Compound 1): chitosan $(1.8 \mathrm{~g}, 12 \mathrm{mmol}), 5.4 \mathrm{~g}$ $\mathrm{N}$-bromobutanimide, $8.55 \mathrm{~g}$ triphenylphosphine $16 \mathrm{~mL}$ of aqueous sodium hydroxide solution $(15 \%$, $w / v)$, and $18 \mathrm{~mL}$ of iodomethane were added to $100 \mathrm{~mL}$ of $\mathrm{N}$-methyl-2-pyrrolidone (NMP) and stirred at $60^{\circ} \mathrm{C}$ under an argon atmosphere for $2 \mathrm{~h}$. The mixture was precipitated into ethanol, and the precipitate was collected by filtration and washed by ethanol. The products were dried at $60^{\circ} \mathrm{C}$ for $24 \mathrm{~h}$, yield: 71.1\%; FT-IR (KBr film): $v 3421\left(\mathrm{NH}_{2}\right.$ and $\left.\mathrm{OH}\right), v 1469$ (C-H of quaternary ammonium). ${ }^{1} \mathrm{H}$ NMR (500 MHz, DMSO- $\left.d_{6}\right): \delta 3.27$ ppm $\left(\mathrm{CH}_{3}-\mathrm{N}\right) ; \delta 3.34-5.26$ (pyranose rings).

6-Bromo-6-deoxy- $\mathrm{N}$-trimethyl quaternary ammonium chitosan (Compound 2): compound 1 $(2.08 \mathrm{~g}, 6.5 \mathrm{mmol}), 5.78 \mathrm{~g}$ sodium iodide, $12 \mathrm{~mL}$ of aqueous sodium hydroxide solution $(15 \%, w / v)$, and $18 \mathrm{~mL}$ of iodomethane were added to $100 \mathrm{~mL}$ of NMP and stirred at $60^{\circ} \mathrm{C}$ under an argon atmosphere for $2 \mathrm{~h}$. The mixture was precipitated into ethanol, and the precipitate was collected by filtration. The unreacted NBS, TPP, and other outgrowth were extracted in a Soxhlet apparatus with ethanol and acetone for $48 \mathrm{~h}$, respectively. The products were dried at $60{ }^{\circ} \mathrm{C}$ for $24 \mathrm{~h}$, yield: $67.9 \% ;{ }^{1} \mathrm{H} \mathrm{NMR}$ (500 MHz, DMSO- $\left.d_{6}\right)$ : $\delta 3.44$ ppm $\left(\mathrm{CH}_{3}-\mathrm{N}\right) ; \delta 3.34-5.26$ (pyranose rings), $3.75\left(\mathrm{CH}_{2} \mathrm{Br}\right) \mathrm{ppm}$.

6-Azido-6-deoxy- $N$-trimethyl quaternary ammonium chitosan (Compound 3): compound 2 $(0.788 \mathrm{~g}, 2 \mathrm{mmol})$, and $0.65 \mathrm{~g}$ sodium azide were added to $45 \mathrm{~mL}$ of NMP and stirred for $4 \mathrm{~h}$ at $80{ }^{\circ} \mathrm{C}$ under an argon atmosphere. The mixture was precipitated into ethanol, and the precipitate was collected by filtration. After being extracted in a Soxhlet apparatus with ethanol for $48 \mathrm{~h}$ and being dialyzed against deionized water for $48 \mathrm{~h}$ to remove the probable remained sodium azide, the 
products were dried at $60^{\circ} \mathrm{C}$ for $24 \mathrm{~h}$, yield: $67.9 \%$; FT-IR (thin film): $v 3432\left(\mathrm{NH}_{2}\right.$ and $\mathrm{OH}$ ), $v 2105$ (C-6-azido), v 1477 (C-H of quaternary ammonium); ${ }^{1} \mathrm{H}$ NMR (500 MHz, DMSO- $\left.d_{6}\right): \delta 3.44$ ppm $\left(\mathrm{CH}_{3}-\mathrm{N}\right) ; \delta 3.34-5.26$ (pyranose rings), $4.0\left(\mathrm{CH}_{2} \mathrm{~N}_{3}\right) \mathrm{ppm}$.

\subsubsection{Synthesis of Chitosan Derivative Bearing 1,2,3-Triazole (4) and 1,2,3-Triazolium (5)}

Compound 4: compound $3(1.0 \mathrm{mmol}), 12 \mathrm{mg}$ cuprous iodide, terminal alkynes (propargyl alcohol, ethynylbenzene, 3-ethynylpyridine, and 3-ethynylthiophene) $(2.0 \mathrm{mmol})$, and $3 \mathrm{~mL}$ of triethylamine were added to $20 \mathrm{~mL}$ of dimethyl sulfoxide and stirred at $75^{\circ} \mathrm{C}$ under an argon atmosphere for $48 \mathrm{~h}$. The mixture was filtered and the filtrate was collected and precipitated into ethanol. The precipitate was washed with saturated solution of potassium iodide and filtered. The unreacted alkyne was extracted in a Soxhlet extractor with ethanol for $48 \mathrm{~h}$. The products were dried at $60^{\circ} \mathrm{C}$ for $24 \mathrm{~h}$.

4a: yield: 72.6\%; DS: 0.81; FT-IR (thin film): $v 3432\left(\mathrm{NH}_{2}\right.$ and $\left.\mathrm{OH}\right), v 1465$ (C-H of quaternary ammonium); ${ }^{1} \mathrm{H}$ NMR (500 MHz, DMSO- $\left.d_{6}\right): \delta 3.4 \mathrm{ppm}\left(\mathrm{CH}_{3}-\mathrm{N}^{+}\right) ; \delta 4.53$ (triazole- $\left.\mathrm{CH}_{2}-\mathrm{OH}\right) ; \delta 7.88$ (triazole-5-H).

4b: yield: 51.9\%; DS: 0.75; FT-IR (thin film): $v 3424\left(\mathrm{NH}_{2}\right.$ and $\left.\mathrm{OH}\right), v 1473(\mathrm{C}-\mathrm{H}$ of quaternary ammonium), $v 767$ and 694 (C-H of benzene); ${ }^{1} \mathrm{H}$ NMR (500 MHz, DMSO- $\left.d_{6}\right): \delta 3.4 \mathrm{ppm}\left(\mathrm{CH}_{3}-\mathrm{N}^{+}\right)$; 8 7.38-7.47 (benzene-H); 7.82 (triazole-5-H).

4c: yield: 51.9\%; DS: 0.72; FT-IR (thin film): $v 3421\left(\mathrm{NH}_{2}\right.$ and $\left.\mathrm{OH}\right), v 1473(\mathrm{C}-\mathrm{H}$ of quaternary ammonium), $v 806$ and 709 (C-H of pyridine); ${ }^{1} \mathrm{H}$ NMR (500 MHz, DMSO- $\left.d_{6}\right): \delta 3.4 \mathrm{ppm}\left(\mathrm{CH}_{3}-\mathrm{N}^{+}\right)$; 7.53 (triazole-5-H); 8 8.24-9.07 (pyridine-H).

4d: yield: 51.9\%; DS: 0.83; FT-IR (thin film): $v 3428\left(\mathrm{NH}_{2}\right.$ and $\left.\mathrm{OH}\right), v 1473$ (C-H of quaternary ammonium), $v 709$ (C-H of thiophene); ${ }^{1} \mathrm{H}$ NMR (500 MHz, DMSO- $\left.d_{6}\right): \delta 3.4 \mathrm{ppm}\left(\mathrm{CH}_{3}-\mathrm{N}^{+}\right) ; \delta 7.16$ (thiophene-H); 7.58 (triazole-5-H).

Chitosan derivative bearing 1,2,3-triazolium (Compound 5) were prepared according to the methods reported by Tan [32]. A solution of compound $4(1 \mathrm{mmol})$ and iodomethane $(0.187 \mathrm{~mL}$, $3 \mathrm{mmol}$ ) in $15 \mathrm{~mL}$ of DMSO was stirred at $60^{\circ} \mathrm{C}$ for $24 \mathrm{~h}$. Afterwards, the remaining iodomethane was evaporated, and the reaction mixture was precipitated into $100 \mathrm{~mL}$ of acetone. The solid product was filtered, washed with acetone three times. After being dialyzed against deionized water for $48 \mathrm{~h}$, the chitosan derivative (5) was obtained by lyophilization of their aqueous solutions.

5a: yield: 98.5\%; DS: 0.72; FT-IR (thin film): $v 3417\left(\mathrm{NH}_{2}\right.$ and $\left.\mathrm{OH}\right), v 1473$ (C-H of quaternary ammonium); ${ }^{1} \mathrm{H}$ NMR (500 MHz, DMSO- $\left.d_{6}\right): \delta 3.4 \mathrm{ppm}\left(\mathrm{CH}_{3}-\mathrm{N}^{+}\right) ; \delta 4.25$ (triazole- $\left.\mathrm{CH}_{2}-\mathrm{OH}\right) ; \delta 4.55$ (triazolium- $\left.\mathrm{CH}_{3}\right) ; \delta 8.31$ (triazole-5-H).

5b: yield: 94.1\%; DS: 0.72; FT-IR (thin film): $v 3397\left(\mathrm{NH}_{2}\right.$ and $\left.\mathrm{OH}\right), v 1469$ (C-H of quaternary ammonium), $v 763$ and 694 (C-H of benzene); ${ }^{1} \mathrm{H}$ NMR (500 MHz, DMSO- $\left.d_{6}\right): \delta 3.4 \mathrm{ppm}\left(\mathrm{CH}_{3}-\mathrm{N}^{+}\right)$; $\delta 4.34$ (triazolium- $\mathrm{CH}_{3}$ ); $\delta$ 7.37-7.47 (benzene-H); $\delta 8.33$ (triazole-5-H).

5c: yield: 73.5\%; DS: 0.69; FT-IR (thin film): $v 3421\left(\mathrm{NH}_{2}\right.$ and $\left.\mathrm{OH}\right), v 1477$ (C-H of quaternary ammonium), $v 809$ and 671 (C-H of pyridine); ${ }^{1} \mathrm{H}$ NMR (500 MHz, DMSO- $\left.d_{6}\right): \delta 3.4 \mathrm{ppm}\left(\mathrm{CH}_{3}-\mathrm{N}^{+}\right)$; $\delta 4.47$ (triazolium and pyridinium- $\mathrm{CH}_{3}$ ); $\delta 8.99$ (pyridine-H); $\delta 8.27$ (triazole-5-H).

5d: yield: 73.5\%; DS: 0.75; FT-IR (thin film): $3421\left(\mathrm{NH}_{2}\right.$ and $\left.\mathrm{OH}\right), v 1473(\mathrm{C}-\mathrm{H}$ of quaternary ammonium), $v 713$ (C-H of thiophene); ${ }^{1} \mathrm{H}$ NMR (500 MHz, DMSO- $\left.d_{6}\right): \delta 3.4 \mathrm{ppm}\left(\mathrm{CH}_{3}-\mathrm{N}^{+}\right) ; \delta 4.41$ (triazolium- $\mathrm{CH}_{3}$ ); $\delta 7.16$ (thiophene-H); 8.18 (triazole-5-H).

\subsection{Antioxidant Assay}

\subsubsection{DPPH-Radical Scavenging Ability Assay}

The DPPH-radical scavenging capacity of the products were evaluated by the following method [33]: DPPH in ethanol $(180 \mu \mathrm{mol} / \mathrm{L})$ and sample solution $(10 \mathrm{mg} / \mathrm{mL})$ were first prepared. The reaction mixture, a total volume of $3.0 \mathrm{~mL}$, containing the samples solution $(0.03,0.06,0.12,0.24$ and $0.48 \mathrm{~mL})$, were incubated with water $(0.97,0.94,0.88,0.76$ and $0.52 \mathrm{~mL})$, and DPPH $(2 \mathrm{~mL})$ at $25^{\circ} \mathrm{C}$ for $30 \mathrm{~min}$. The concentration of hydroxyl-radical was $0.1,0.2,0.4,0.8$, and $1.6 \mathrm{mg} / \mathrm{ml}$, respectively. Then, 
the absorbance of the remained DPPH radical was measured at $517 \mathrm{~nm}$ against a blank. Three replicates for each sample concentration were tested and the scavenging effect was obtained according to the following equation:

$$
\text { Scavenging effect }(\%)=\left[1-\frac{A_{\text {sample } 517 n m}-A_{\text {control 517nm }}}{A_{\text {blank } 517 n m}}\right] \times 100 \%
$$

where $A_{\text {sample } 517 \mathrm{~nm}}$ is the absorbance of the sample at $517 \mathrm{~nm}, \mathrm{~A}_{\text {blank }} 517 \mathrm{~nm}$ is the absorbance of the blank at $517 \mathrm{~nm}$ and $A_{\text {control } 517 n m}$ represents the absorbance of the control (distilled water instead of DPPH) at $517 \mathrm{~nm}$. The antioxidant activity was expressed as $\mathrm{IC}_{50}$, which was defined as the concentration of compound required for inhibition of the radical formation by $50 \%$. Vitamin $C$ was used as the positive control.

\subsubsection{Superoxide-Radical Scavenging Ability Assay}

The superoxide radical scavenging ability was assessed following Xing's methods with minor modification [34]. The Tris- $\mathrm{HCl}$ buffer $(16 \mathrm{mM}, \mathrm{pH} 8.0)$ and sample solution $(1 \mathrm{mg} / \mathrm{mL}$ and $5 \mathrm{mg} / \mathrm{mL})$ were first prepared. Then the solution of nicotinamide adenine dinucleotide reduced (NADH 365.7 $\mu \mathrm{g} / \mathrm{mL}$ ), nitro blue tetrazolium (NBT $245.3 \mu \mathrm{g} / \mathrm{mL}$ ), and phenazine mothosulfate (PMS $18.38 \mu \mathrm{g} / \mathrm{mL}$ ) were prepared in Tris- $\mathrm{HCl}$ buffer $(\mathrm{pH}=8.0)$. The reaction mixture, a total volume $3.0 \mathrm{~mL}$, containing the samples solution (A: $1 \mathrm{mg} / \mathrm{mL}, 0.03,0.075,0.15$, and $0.225 \mathrm{~mL}$; $\mathrm{B}: 5 \mathrm{mg} / \mathrm{mL}, 0.06,0.12,0.24$, 0.48 and $0.96 \mathrm{~mL}$ ), were incubated with Tris- $\mathrm{HCl}$ buffer (A: $1.47,1.425,1.35$ and 1.225; B: 1.44, 1.38, 1.26, 1.02 and $0.54 \mathrm{~mL})$, NADH $(0.5 \mathrm{~mL})$, NBT $(0.5 \mathrm{~mL})$, and PMS $(0.5 \mathrm{~mL})$ at $25{ }^{\circ} \mathrm{C}$ for $5 \mathrm{~min}$. The concentration of hydroxyl-radical was $0.01,0.025,0.05,0.075,0.1,0.2,0.4,0.8,1.6 \mathrm{mg} / \mathrm{mL}$, respectively. The absorbance was read at $560 \mathrm{~nm}$ against blank. Three replicates for each sample were tested and the capability of scavenging superoxide radical was calculated using the following equation:

$$
\text { Scavenging effect }(\%)=\left[1-\frac{\mathrm{A}_{\text {sample } 560 \mathrm{~nm}}-\mathrm{A}_{\text {control } 560 \mathrm{~nm}}}{\mathrm{~A}_{\text {blank }} 560 \mathrm{~nm}}\right] \times 100 \%
$$

where $A_{\text {sample } 517 \mathrm{~nm}}$ is the absorbance of the sample at $560 \mathrm{~nm}$, and $\mathrm{A}_{\text {control } 560 \mathrm{~nm}}$ is the absorbance of the negative control (distilled water instead of NADH for each concentration) and $A_{\text {blank }} 560 \mathrm{~nm}$ is the absorbance of the blank (distilled water instead of the samples). The superoxide radical-scavenging activity was expressed as the $\mathrm{IC}_{50}$ value. Vitamin $\mathrm{C}$ was used as a positive control.

\subsubsection{Hydroxyl-Radical Scavenging Ability Assay}

The test of hydroxyl-radical scavenging ability was carried out according to Liu's methods with minor modification [35]. The phosphate-buffered saline $(\mathrm{pH}=7.4)$ and sample solution $(10 \mathrm{mg} / \mathrm{mL})$ were first prepared. Then the solution of $\mathrm{H}_{2} \mathrm{O}_{2}(3 \%)$ and safranine $\mathrm{T}(360 \mu \mathrm{g} / \mathrm{mL})$ were prepared in phosphate-buffered saline $(\mathrm{pH}=7.4)$. The solution of EDTA-Fe ${ }^{2+}(2 \mathrm{mmol} / \mathrm{L})$ was prepared in water. The reaction mixture, a total volume $4.5 \mathrm{~mL}$, containing sample solution $(0.045,0.09,0.18,0.36$ and $0.72 \mathrm{~mL})$, were incubated with water $(0.955,0.91,0.82,0.64$ and $0.28 \mathrm{~mL}), \mathrm{EDTA}_{-} \mathrm{Fe}^{2+}$ solution (0.5 mL), safranine $\mathrm{T}(1 \mathrm{~mL})$, and $\mathrm{H}_{2} \mathrm{O}_{2}(1 \mathrm{~mL})$ in potassium phosphate buffer $(0.51 \mathrm{~mL}, \mathrm{pH} 7.4)$ at $37^{\circ} \mathrm{C}$ for $30 \mathrm{~min}$. The concentration of hydroxyl-radical was $0.1,0.2,0.4,0.8,1.6 \mathrm{mg} / \mathrm{ml}$, respectively. The absorbance of the mixture was measured at $520 \mathrm{~nm}$. In the blank, samples were substituted with distilled water. Meanwhile, in the negative control, $\mathrm{H}_{2} \mathrm{O}_{2}$ was substituted with potassium phosphate buffer. Three replicates for each sample were tested. The capability of scavenging hydroxyl radicals of the products was computed using the following equation:

$$
\text { Scavenging effect }(\%)=\frac{A_{\text {sample } 520 \mathrm{~nm}}-A_{\text {blank } 520 \mathrm{~nm}}}{A_{\text {control } 520 \mathrm{~nm}}-\mathrm{A}_{\text {blank } 520 \mathrm{~nm}}} \times 100 \%
$$


where $A_{\text {blank } 520 \mathrm{~nm}}$ is the absorbance of the blank at $520 \mathrm{~nm}$; $A_{\text {sample } 520 \mathrm{~nm}}$ is the absorbance of the sample at $520 \mathrm{~nm} ; \mathrm{A}_{\text {control } 520 \mathrm{~nm}}$ is the absorbance of the control at $520 \mathrm{~nm}$. The antioxidant activity of test compounds was expressed as $\mathrm{IC}_{50}$. Vitamin $\mathrm{C}$ was used as a positive control.

Each experiment was performed in three replicates and the data were expressed as mean \pm standard deviation (SD). Significant difference analysis was performed using Duncan's multiple range test. A level of $p<0.05$ was considered as statistically significant.

\section{Conclusions}

We investigated the possible radical scavenging ability of chitosan and its derivatives with 1,2,3-triazole or 1,2,3-triazolium because these groups may improve the antioxidant property of chitosan. Firstly, we designed and synthesized a group of novel water soluble chitosan derivatives containing 1,2,3-triazole or 1,2,3-triazolium. Through chemical modification, chitosan was derivatized with hydrophilic group (quaternary ammonium salt) and biologically active group (triazole or triazolium), which enabled the product to have better antioxidant property and water solubility. The radical scavenging activity against three kinds of free radicals was tested. All the chitosan derivatives exhibited higher radical scavenging activity than chitosan. Moreover, the triazolium group was found to be a more efficient group than triazole and contributed a lot to the radical scavenging ability of chitosan derivatives. The experiment data demonstrated that the chemical modification of chitosan with triazolium functional groups was conducive to improving the antioxidant activity of chitosan. These findings mentioned above bring further evidence that chitosan derivatives are active and have the potential of becoming alternatives of free radical scavenger.

Acknowledgments: We thank the National Natural Science Foundation of China (41576156), Natural Science Foundation of Shandong Province of China (ZR2017BD015), Yantai Science and Technology Development Plan (2015ZH078), and Technology Research Funds Projects of Ocean (No. 2015418022-3) for financial support of this work.

Author Contributions: Qing Li participated to design the experiments, wrote the paper, and was a chief experimenter. Xueqi Sun also performed the experiments and participated to analyze the data. Guodong Gu participated to analyze the data and was responsible for the language modification. Zhanyong Guo was the chief designer and the instructor of the experiment, and analyzed the experimental data.

Conflicts of Interest: No conflicting relationship exists for any author.

\section{Abbreviations}

The following abbreviations are used in this manuscript:

$\begin{array}{ll}\text { DPPH } & 1,1-\text { Diphenyl-2-picrylhydrazyl } \\ \text { DMSO } & \text { Dimethyl Sulphoxide } \\ \text { DMF } & N, N \text {-Dimethylformamide } \\ \text { EDTA } & \text { Ethylenediaminetetraacetic acid } \\ \text { NMP } & N \text {-Methyl pyrrolidone }\end{array}$

\section{References}

1. Mahakunakorn, P.; Tohda, M.; Murakami, Y.; Matsumoto, K.; Watanabe, H. Antioxidant and free radical-scavenging activity of Choto-san and its related constituents. Biol. Pharm. Bull. 2004, 27, 38-46. [CrossRef] [PubMed]

2. Galano, A.; Mazzone, G.; Alvarez-Diduk, R.; Marino, T.; Alvarez-Idaboy, J.R.; Russo, N. Food Antioxidants: Chemical Insights at the Molecular Level. Annu. Rev. Food Sci. Technol. 2016, 7, 223-352. [CrossRef] [PubMed]

3. Soobrattee, M.A.; Neergheen, V.S.; Luximon-Ramma, A.; Aruoma, O.I.; Bahorun, T. Phenolics as potential antioxidant therapeutic agents: Mechanism and actions. Mutat. Res. Fundam. Mol. Mach. 2005, 579, $200-213$. [CrossRef] [PubMed]

4. Jabbari, M.; Jabbari, A. DPPH radical-scavenging activity and kinetics of antioxidant agent hesperidin in pure aqueous micellar solutions. Bull. Chem. Soc. Jpn. 2016, 89, 869-875. [CrossRef] 
5. Nakajima, A.; Yamaguchi, T.; Hattori, G.; Sakurai, Y.; Kawamura, M.; Kawai, K.; Miyake, Y.; Kanaori, K.; Tajima, K. Accuracy and validity of AREC (Alkoxy Radical Elimination Capacity) assay in evaluating the antioxidant abilities of various biosubstances. Bull. Chem. Soc. Jpn. 2017, 90, 223-230. [CrossRef]

6. Gehrcke, M.; Giuliani, L.M.; Ferreira, L.M.; Barbieri, A.V.; Sari, M.H.M.; da Silveira, E.F.; Azambuja, J.H.; Nogueira, C.W.; Braganhol, E.; Cruz, L. Enhanced photostability, radical scavenging and antitumor activity of indole-3-carbinol-loaded rose hip oil nanocapsules. Mater. Sci. Eng. C 2017, 74, 279-286. [CrossRef] [PubMed]

7. Tan, W.; Zhang, J.; Luan, F.; Wei, L.; Chen, Y.; Dong, F.; Li, Q.; Guo, Z. Design, synthesis of novel chitosan derivatives bearing quaternary phosphonium salts and evaluation of antifungal activity. Int. J. Biol. Macromol. 2017, 102, 704-711. [CrossRef] [PubMed]

8. Tan, W.; Li, Q.; Wei, L.; Wang, P.; Gao, Z.; Chen, Y.; Dong, F.; Guo, Z. Synthesis, characterization, and antifungal property of starch derivatives modified with quaternary phosphonium salts. Mater. Sci. Eng. C 2017, 76, 1048-1056. [CrossRef] [PubMed]

9. Li, Q.; Zhang, C.; Tan, W.; Gu, G.; Guo, Z. Novel amino-pyridine functionalized chitosan quaternary ammonium derivatives: Design, synthesis, and antioxidant activity. Molecules 2017, 22, 156-165. [CrossRef] [PubMed]

10. Ahmed, J.; Thomas, L.; Taher, A.; Joseph, A. Impact of high pressure treatment on functional, rheological, pasting, and structural properties of lentil starch dispersions. Carbohydr. Polym. 2016, 152, 639-647. [CrossRef] [PubMed]

11. Adak, S.; Banerjee, R. A green approach for starch modification: Esterification by lipase and novel imidazolium surfactant. Carbohydr. Polym. 2016, 150, 359-368. [CrossRef] [PubMed]

12. Fan, L.; Yang, J.; Wu, H.; Hu, Z.; Yi, J.; Tong, J.; Zhu, X. Preparation and characterization of quaternary ammonium chitosan hydrogel with significant antibacterial activity. Int. J. Biol. Macromol. 2015, 79, 830-836. [CrossRef] [PubMed]

13. Guo, Z.; Liu, H.; Chen, X.; Ji, X.; Li, P. Hydroxyl radicals scavenging activity of $N$-substituted chitosan and quaternized chitosan. Bioorg. Med. Chem. Lett. 2006, 16, 6348-6350. [CrossRef] [PubMed]

14. Liu, M.; Min, L.; Zhu, C.; Rao, Z.; Liu, L.; Xu, W.; Luo, P.; Fan, L. Preparation, characterization and antioxidant activity of silk peptides grafted carboxymethyl chitosan. Int. J. Biol. Macromol. 2017, 104, 732-738. [CrossRef] [PubMed]

15. Wei, L.; Li, Q.; Tan, W.; Dong, F.; Luan, F.; Guo, Z. Synthesis, characterization, and the antioxidant activity of double quaternized chitosan derivatives. Molecules 2017, 22, 501-601. [CrossRef] [PubMed]

16. Eswaran, S.; Adhikari, A.V.; Shetty, N.S. Synthesis and antimicrobial activities of novel quinoline derivatives carrying 1,2,4-triazole moiety. Eur. J. Med. Chem. 2009, 44, 4637-4647. [CrossRef] [PubMed]

17. Abuo-Rahma Gel, D.; Abdel-Aziz, M.; Beshr, E.A.; Ali, T.F. 1,2,4-Triazole/oxime hybrids as new strategy for nitric oxide donors: Synthesis, anti-inflammatory, ulceroginicity and antiproliferative activities. Eur. J. Med. Chem. 2014, 71, 185-198. [CrossRef] [PubMed]

18. Hou, Y.P.; Sun, J.; Pang, Z.H.; Lv, P.C.; Li, D.D.; Yan, L.; Zhang, H.J.; Zheng, E.X.; Zhao, J.; Zhu, H.L. Synthesis and antitumor activity of 1,2,4-triazoles having 1,4-benzodioxan fragment as a novel class of potent methionine aminopeptidase type II inhibitors. Bioorg. Med. Chem. 2011, 19, 5948-5954. [CrossRef] [PubMed]

19. Ouyang, X.; Chen, X.; Piatnitski, E.L.; Kiselyov, A.S.; He, H.Y.; Mao, Y.; Pattaropong, V.; Yu, Y.; Kim, K.H.; Kincaid, J.; et al. Synthesis and structure-activity relationships of 1,2,4-triazoles as a novel class of potent tubulin polymerization inhibitors. Bioorg. Med. Chem. Lett. 2005, 15, 5154-5159. [CrossRef] [PubMed]

20. Park, H.; Bahn, Y.J.; Ryu, S.E. Structure-based de novo design and biochemical evaluation of novel Cdc25 phosphatase inhibitors. Bioorg. Med. Chem. Lett. 2009, 19, 4330-4334. [CrossRef] [PubMed]

21. Aizpurua, J.M.; Fratila, R.M.; Monasterio, Z.; Perez-Esnaola, N.; Andreieff, E.; Irastorza, A.; Sagartzazu-Aizpurua, M. Triazolium cations: From the "click" pool to multipurpose applications. New J. Chem. 2014, 38, 474-480. [CrossRef]

22. Li, Q.; Tan., W.; Zhang, C.; Gu, G.; Guo, Z. Novel triazolyl-functionalized chitosan derivatives with different chain lengths of aliphatic alcohol substituent: Design, synthesis, and antifungal activity. Carbohydr. Res. 2015, 418, 44-49. [CrossRef] [PubMed]

23. Li, Q.; Tan., W.; Zhang, C.; Gu, G.; Guo, Z. Synthesis of water soluble chitosan derivatives with halogeno-1,2,3-triazole and their antifungal activity. Int. J. Biol. Macromol. 2016, 91, 623-629. [CrossRef] [PubMed] 
24. Ren, J.; Li, Q.; Dong, F.; Feng, Y.; Guo, Z. Phenolic antioxidants-functionalized quaternized chitosan: Synthesis and antioxidant properties. Int. J. Biol. Macromol. 2013, 53, 77-81. [CrossRef] [PubMed]

25. Dong, F.; Zhang, J.; Yu, C.; Li, Q.; Ren, J.; Wang, G.; Gu, G.; Guo, Z. Synthesis of amphiphilic aminated inulin via 'click chemistry' and evaluation for its antibacterial activity. Bioorg. Med. Chem. Lett. 2014, 24, 4590-4593. [CrossRef] [PubMed]

26. Lu, Y.L.; Gong, X.D.; Ju, X.H.; Ji, G.F.; Xiao, H.M. Structures and properties of 1,2,3-triazoles and 1,2,4-triazoles. Chin. J. Struct. Chem. 2006, 25, 582-588.

27. Sood, R.; Obadia, M.M.; Mudraboyina, B.P.; Zhang, B.; Serghei, A.; Bernard, J.; Drockenmuller, E. 1,2,3-Triazolium-based poly(acrylate ionic liquid)s. Polymer 2014, 55, 3314-3319. [CrossRef]

28. Chen, Y.; Wang, F.J.; Yun, D.R.; Guo, Y.W.; Ye, Y.C.; Wang, Y.X.; Tan, H.M. Preparation of a C6 quaternary ammonium chitosan derivative through a chitosan schiff base with click chemistry. J. Appl. Polym. Sci. 2013, 129, 3185-3191. [CrossRef]

29. El Ashry, E.S.H.; El-Rafey, E.; Rezki, N.; Abou-Elnaga, H.H.; Bakry, W.M.A.; Boghdadi, Y.M. Evaluation of some functionalized imidazoles and 1,2,4-triazoles as antioxidant additives for industrial lubricating oils and correlating the results with the structures of additives using empirical AM1 calculations. J. Saudi Chem. Soc. 2014, 18, 443-449. [CrossRef]

30. Tan, W.; Zhang, J.; Luan, F.; Wei, L.; Li, Q.; Dong, F.; Guo, Z. Synthesis, characterization, and antifungal evaluation of novel 1,2,3-triazolium-functionalized starch derivative. Int. J. Biol. Macromol. 2017, 101, 845-851. [CrossRef] [PubMed]

31. Li, Q.; Qiu, L.; Tan, W.; Gu, G.; Guo, Z. Novel 1,2,3-triazolium-functionalized inulin derivatives: Synthesis, free radical-scavenging activity, and antifungal activity. RSC Adv. 2017, 7, 42225-42232. [CrossRef]

32. Tan, W.; Li, Q.; Gao, Z.; Qiu, S.; Dong, F.; Guo, Z. Design, synthesis of novel starch derivative bearing 1,2,3-triazolium and pyridinium and evaluation of its antifungal activity. Carbohydr. Polym. 2017, 157, 236-243. [CrossRef] [PubMed]

33. Hu, Y.; Zhang, J.; Yu, C.; Li, Q.; Dong, F.; Wang, G.; Guo, Z. Synthesis, characterization, and antioxidant properties of novel inulin derivatives with amino-pyridine group. Int. J. Biol. Macromol. 2014, 70, 44-49. [CrossRef] [PubMed]

34. Ren, J.; Liu, J.; Dong, F.; Guo, Z. Highly efficient synthesis and antioxidant activity of O-(aminoethyl)inulin. Carbohydr. Polym. 2011, 83, 1240-1244. [CrossRef]

35. Liu, J.; Sun, H.; Dong, F.; Xue, Q.; Wang, G.; Qin, S.; Guo, Z. The influence of the cation of quaternized chitosans on antioxidant activity. Carbohydr. Polym. 2009, 78, 439-443. [CrossRef] 